f. med. Genet. (1969). 6, 113.

\title{
Syndrome of Retardation with Urogenital and Skeletal Anomalies (Smith-Lemli-Opitz Syndrome): \\ Clinical Features and Mode of Inheritance
}

\author{
L. DALLAIRE
}

From Medical Genetics Laboratory, Douglas Hospital, Montreal 204, and The McGill University-Montreal Children's Hospital Research Institute, Montreal, Canada

A syndrome characterized by multiple skeletal and urogenital anomalies was first described by Smith, Lemli, and Opitz (1964). Other investigators (Pinsky and DiGeorge, 1965; Gibson, 1965; Blair and Martin, 1966; Dallaire and Fraser, 1966; Kenis and Hustinx, 1967; Fine, Gwinn, and Young, 1968) made similar observations of this syndrome which is characterized by foetal hypoactivity, intra- uterine growth retardation, breech presentation, failure to thrive, vomiting in infancy, microcephaly, mental deficiency, blepharoptosis, short nose with a broad bridge and anteverted nares, broad maxillary alveolus, micrognathia, short neck, hypospadias and cryptorchidism (in males), simian palmar creases, metatarsus adductus, pedal syndactyly, and abnormal dermatoglyphic patterns. Additional data on the clinical features of this syndrome and its mode of inheritance are provided by the following description of 9 affected children from 6 families.

Received July 19, 1968.

1 when the proband (III.2), Case 1, was born. Subsequently, the mother had 11 pregnancies including 5 normal children, 2 more abnormal children, and 4 spontaneous abortions in the $3 \mathrm{rd}$ month of gestation. There was no history of undue exposure to radiation or drug intake other than vitamin pills during the pregnancy. One of the father's sisters (II.20) had 5 children, one of whom is Case $\mathbf{4}$ of this report.

Case 1. III.2, a female born after a 36-week gestation, had the cord around her neck. Her weight was $3000 \mathrm{~g}$. She was admitted to another hospital at 1 month of age for treatment of recurrent respiratory infections, malnutrition, and investigation of convulsive disorders. Physical examination revealed a malnourished hypotonic 


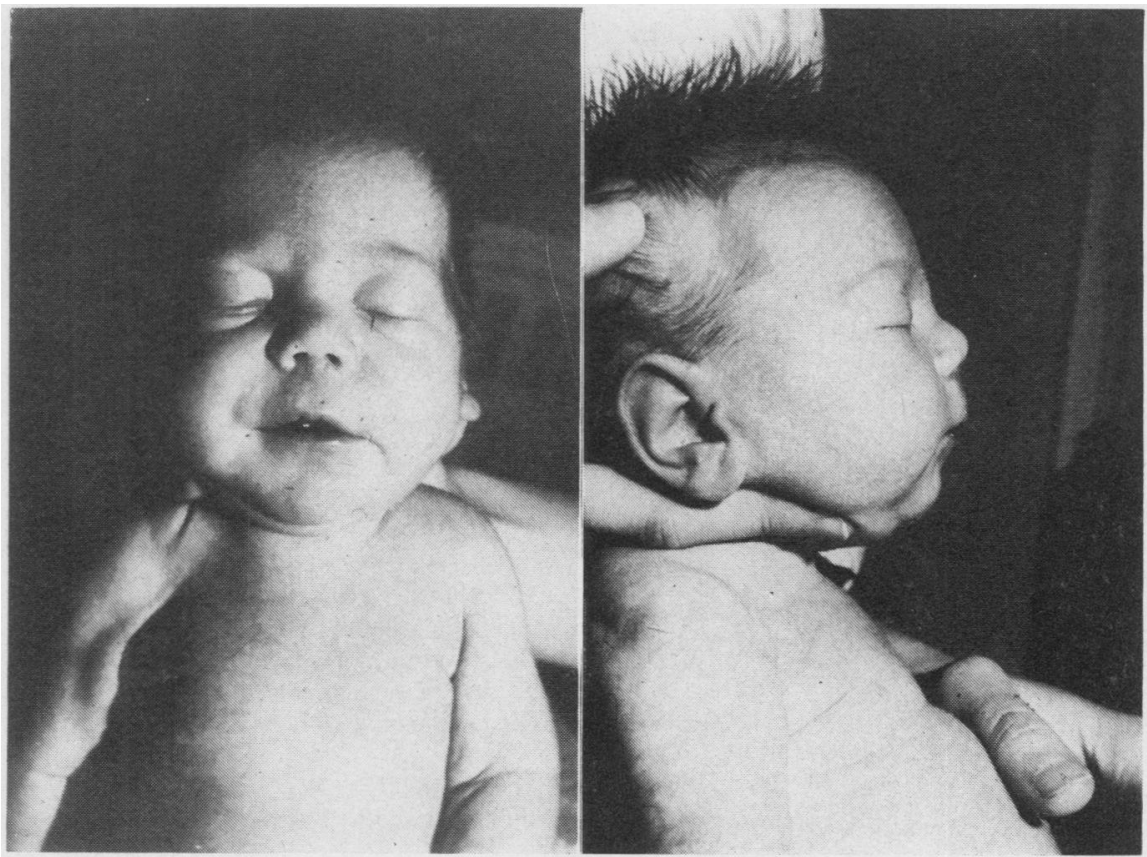

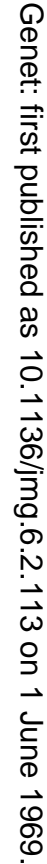

(a) Front view of face.

(b) Profile.

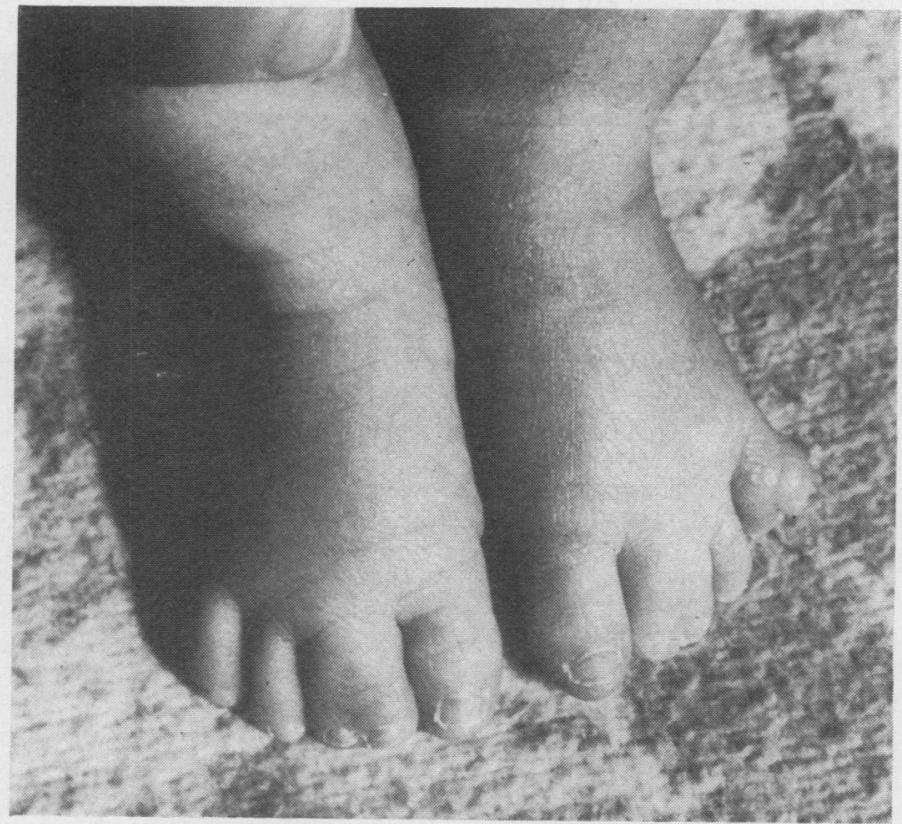

(c) Webbing of toes.

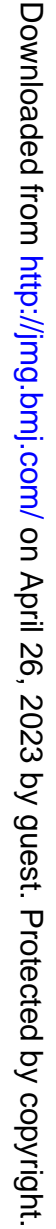


infant, whose head fell backwards when she was picked up. The case history records an odd facies, strabismus, apparent blindness, micrognathia, abnormal ears, and an umbilical hernia. There was cutaneous webbing of the 2nd and 3rd toes on both feet. She was emaciated when she died at 11 months in a mental institution. The necropsy report records a length of $59 \mathrm{~cm}$. The lungs, heart, liver, pancreas, adrenals, and gonads were macroscopically and microscopically normal. The spleen was small, and on microscopy showed very little lymphoid tissue. There was a slight dilatation of the left ureter. The rectum and long sigmoid to lower descending colon were much dilated.

Case 2. III.4 a female born after a 34-week gestation had the cord around her neck and suffered severe anoxia at birth. Her cry was weak. Her weight was $2180 \mathrm{~g}$. and her head circumference was $31 \mathrm{~cm}$. Her face was round and her ears were low set. She had a cleft of the posterior midline of the palate, a short neck, and narrow shoulders. There was an extra small digit on the right hand, composed of only two phalanges. The 2nd and 3rd toes were webbed bilaterally. At the age of 3 months, her length was $47 \mathrm{~cm}$. and her head circumference $32 \mathrm{~cm}$. Her weight was $3125 \mathrm{~g}$. All reflexes were diminished. She was very limp. Her fundi were recorded as abnormal, but not characteristic of a retinitis pigmentosa. The upper lip was fused to a large upper gum. There was some limitation in the abduction of the hips. Radiological examination revealed the presence of spontaneous fractures of the 7th and 8 th ribs. The pelvis bone maturation was delayed. Other films taken at the age of 5 months showed a delayed calcification of the proximal epiphysis of each tibia. She did not follow objects with her eyes. She died at 11 months of age in a mental institution, at which time she had only two teeth, and she was hypertonic. No necropsy was performed.

Case 3. III.7, a male, was born after a normal 40week gestation. The labour was normal but he was cyanotic for several minutes at birth, and his face and extremities were oedematous. Like his sisters, the cord was around the neck. His length was $45 \mathrm{~cm}$., his skull circumference $31 \mathrm{~cm}$., and his weight $3270 \mathrm{~g}$. The patient (Fig. 2) was hypotonic, had a high-pitched cry, and poor sucking reflexes. He regurgitated constantly and had to be fed by tube. The palate was extremely high. His neck was thick and broad. A marked chordae deformity was noted with peno-scrotal hypospadias and failure of development of the scrotum. Both feet showed cutaneous webbing of the 2 nd and 3 rd toes, and a supernumerary digit arising from the proximal phalanx on the lateral side of the fifth toe. Both thumbs were uniphalangeal. There was a radial deviation of the terminal phalanx of the forefingers. The posterosuperior portion of the right helix was absent. His eyes were kept closed. The examination of the fundi revealed that both discs were pale, with a lack of retinal pigmentation. Radiological examination of the chest, upper gastro-intestinal tract, and urinary collecting system did not reveal any abnormality. The patient died at the age of 2 in a mental institution, at which time he was very hypertonic. No necropsy was done.

Family II (Fig. 1). The father's sister (II.20) of Family I had 5 children. She was 27 and her unrelated husband was 28 when the proband (III.15) was born. A brother (III.14) was reported to have died shortly after birth following operation for pyloric stenosis. Both parents were in good health, and had not been exposed to radiation. The mother recalled taking only vitamin and calcium pills during the pregnancies.

Case 4. III.15, a female infant, was born after a 40week gestation complicated by oligohydramnios. The presentation was normal. Her weight was $2300 \mathrm{~g}$. and her length $47.5 \mathrm{~cm}$. She had a cleft palate, micrognathia, a heart defect, an equinovarus deformity of the feet, webbing of the 2nd and 3rd toes bilaterally, and telangiectasiae on the neck and arms. She died suddenly 27 days after birth, and the necropsy confirmed the presence of a persistent ductus arteriosus and foramen ovale. No abnormality of the genito-urinary tract was noted. The liver, pancreas, and spleen were normal macroscopically and microscopically. The internal and external genital organs were normal. We cannot prove that this child had the syndrome, but the presence of similar features in the near relative of a known case makes this a likely interpretation.

\section{Family III (Fig. 3).}

Case 5. III.1, a female infant, was born by breech, after a 42-week gestation, of a 21-year-old mother and 23-year-old father. They were both French Canadian and were unrelated. The pregnancy was uneventful. The patient's weight was $2720 \mathrm{~g}$., length $48.5 \mathrm{~cm}$., and head circumference $32 \mathrm{~cm}$. The infant developed cyanosis shortly after birth, and was transferred to The

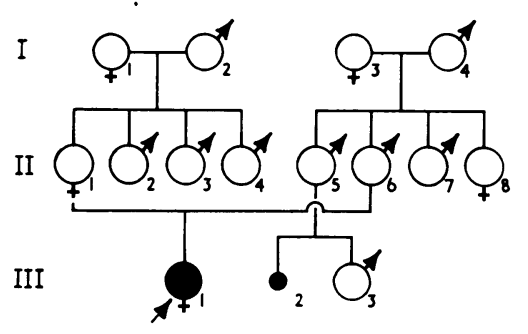

FIG. 3. Pedigree of Family III.

Montreal Children's Hospital for investigation of a heart defect, subsequently diagnosed as a tetralogy of Fallot. She also had an odd facies, low-set ears, upturned nares, a short neck, micrognathia, simian creases, clinodactyly of the fifth fingers, and bilateral syndactyly of the 2nd and 3rd toes. There were biochemical and haematological changes compatible with her cardiac lesion. At 7 months of age her psychomotor development was delayed, her length was $60 \mathrm{~cm}$., and her weight $6680 \mathrm{~g}$. She died at $7 \frac{1}{2}$ months of age of pulmonary complications 
after heart operation. The necropsy confirmed the clinical diagnosis of tetralogy of Fallot, but did not show any major anomaly of the gastro-intestinal or genitourinary systems.

Family IV (Fig. 4). In this family the father's parents were Scottish and the mother's Irish. Both parents were born in Canada. The father was 28 and the mother 26 and in good health when their first affected

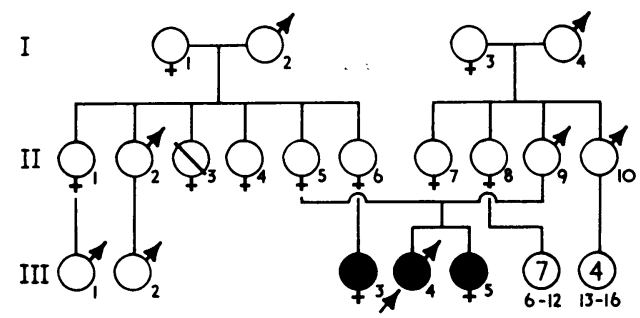

FIG. 4. Pedigree of Families IV and V.

child (III.4), Case 6, was born. The second pregnancy, two years later, also resulted in an abnormal child, Case 7. The mother's sister (II.6) gave birth to an abnormal female infant (III.3), Case 8, of this report.

Case 6. III.4 was born by breech after a full-term uneventful pregnancy. His birthweight was $2990 \mathrm{~g}$. He sat up at the age of 1 year and walked at 2 years. Multiple anomalies were noted at birth: protruding ears with lack of cartilage in the helix, blepharoptosis,

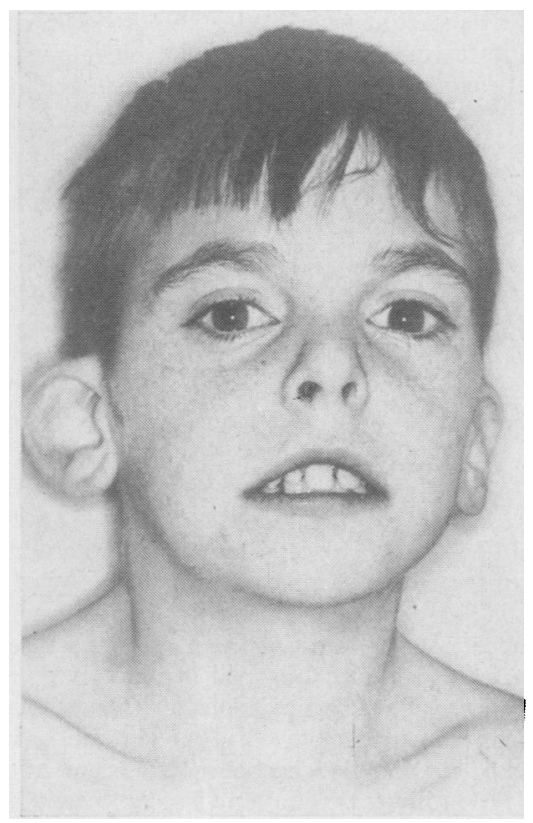

Fig. 5. Case 6, facies. strabismus, cleft palate, micrognathia, minimal webbing of the neck, a right inguinal hernia, and cryptorchidism, constriction of the urethral meatus, equinovarus deformity of the feet, bilateral syndactyly of the 2 nd and 3rd toes. At the age of 10 years the patient (Fig. 5) was still functioning at the level of a 2-year-old child, was speechless, and weighed $23.6 \mathrm{~kg}$. An intravenous pyelogram showed a constriction of the left ureter at the ureteropelvic junction. The radiological examination of the skull showed an accentuation of the digital markings and an occipital bone deformity. The electroencephalogram revealed a wave abnormality projected from the subcortical region. The patient was still alive and severely retarded when this report was prepared.

Case 7. III.5, a female infant, was born after an uncomplicated pregnancy and delivery. Her birthweight was $2900 \mathrm{~g}$. She was hypotonic, had low-set ears, a cleft palate, marked blepharoptosis, epicanthic folds, a broad nose bridge, with anteverted nares, broad maxillary ridges, a short webbed neck, narrow shoulders, bilateral talipes equinovarus, and syndactyly of the 2nd and 3rd toes. At the age of 10 (Fig. 6 ) she presented as a severely

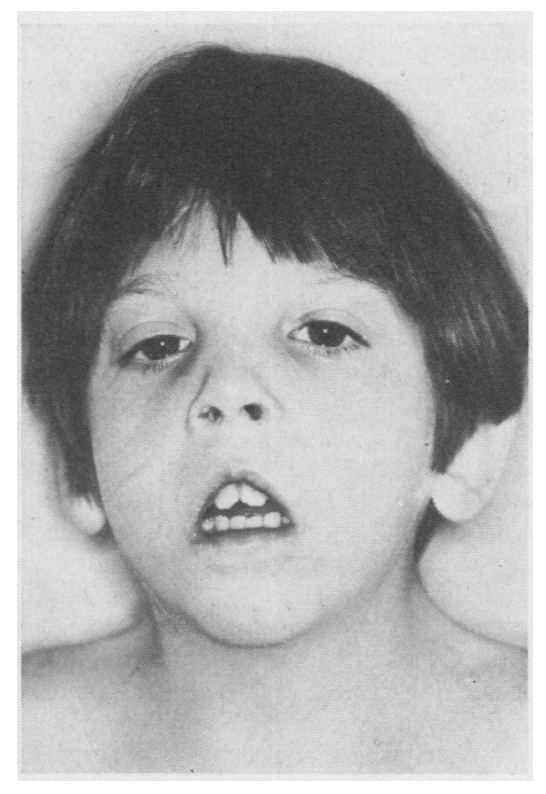

Fig. 6. Case 7, sister of Case 6. Facies.

retarded microcephalic spastic child. Her skull measured $48 \mathrm{~cm}$., her weight was $20 \mathrm{~kg}$., and her height $110 \mathrm{~cm}$. Radiological examinations of the spine and chest were normal.

\section{Family V (Fig. 4).}

Case 8. III.3, a female infant, was the first child of a 29-year-old mother and 41-year-old father. The delivery was complicated by the fact that she was hydrocephalic. She also had epicanthic folds, a broad nose 
bridge with anteverted nares, very low-set ears, a patent foramen ovale and ductus arteriosus, flexion contractures of the fingers on the left hand, clinodactyly, bilateral syndactyly of the 2 nd and 3 rd toes, and left metatarsus adductus. She had a partial simian crease on both hands. She died suddenly 3 days after birth. It seems likely that she was a case of the syndrome $(H$. Soltan, 1968, personal communications), and we included her in the series. A normal male infant was subsequently born to the same parents.

Family VI (Fig. 7). The parents of Case 9 were a young unrelated French Canadian couple. Their first child was a normal female, and the second pregnancy terminated abruptly after 8 months. The father was 26

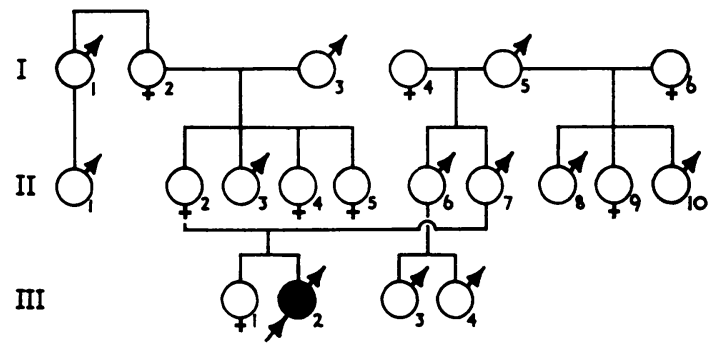

FIg. 7. Pedigree of Family VI.

and the mother 24 years of age when the affected male was born. There was a marked hydramnios. The mother menstruated for the first time at 7 years of age, and the mentrual periods occurred every 20 days until the age of 16 , after which they occurred every 28 days. An uncle on the maternal side (II.1) died in early infancy of hydrocephaly and other malformations of undetermined nature.

Case 9. III.2, a male infant, was born after a 34-week gestation, and his weight was $2000 \mathrm{~g}$. His head circumference was $32 \mathrm{~cm}$. and length $40 \mathrm{~cm}$. He had lowset ears, a cleft palate, blepharoptosis, a broad nose bridge, with anteverted nares, micrognathia, a short neck and narrow shoulders, a ventricular septal defect, a right inguinal hernia and bilateral cryptorchidism, metatarsus abductus on the right, and bilateral syndactyly of the 2nd and 3rd toes. A first median lower tooth appeared after 6 weeks. He smiled at 2 months of age. At the time this report was written, the patient was not thriving well, regurgitated, and was tube fed. He was still hypotonic. No surgical treatment was considered for his heart defect.

\section{Laboratory Findings}

Cytogenetic studies were done by means of peripheral blood cultures (Moorhead et al., 1960) on the parents of 5 of the 6 families, the affected children in Families III, IV, and VI, and 4 of the 5 normal sibs in Family I. A fibroblast culture was done on Case 8 of Family V. The studies were repeated several times and more than 100 cells in the affected children were counted and carefully analysed for variations in chromosome length and arm ratio. No mosaicism was detected. In Family I, the mother had an unusually long chromosome 16, also found in 3 of the 4 normal sibs studied. Since the affected first cousin (III.15) was related to the father we assumed that there was no relation between this chromosomal variant and the affected children. In Family IV, Case 6 had an unusually long chromosome 18: a detailed cytogenetic investigation of the parents and the other affected sib, Case 7, failed to show any obvious familial chromosomal defect. The affected cousin, Case 8, had a normal chromosomal pattern.

Plasma and urine levels of amino acids were studied on the affected children of Families III, IV, and VI by means of paper chromatography, and all were within normal limits. No abnormal significant biochemical findings were noted in these patients.

The dermatoglyphic patterns in the parents and affected children in Families III, IV, VI, and the proband in Family $\mathrm{V}$ are presented in Table $\mathrm{I}$. Cases 5 and 7 had a high number of digital whorls (10 and 9, respectively), but the finger patterns in the parents of Case 5 and the father of Case 7 also showed a high number of whorls. In Family IV, Case 6 had 5 arches, 3 radial loops, and 2 ulnar loops, quite a different pattern from the other cases, and Case 7 had a loop fibular in the hypothenar area of the left sole. Their father had open fields in the hallucal areas, a rare pattern in the normal population, but common in Down's syndrome; their cousin (Case 8) also had unusual digital patterns. The dermatoglyphs had not been recorded in Cases 1, 2, 3, and 4. Blood group studies were done on Family IV and are reported in Table II.

\section{Discussion}

Clinical Considerations. Most cases of Smith-Lemli-Opitz syndrome have in common several abnormal features noted in the introduction to this paper, to which we can add less frequent somatic malformations like cleft palate, heart defect, and polydactyly. The diagnosis of the condition becomes more and more difficult to make since the diversity in phenotypes increases with the number of publications. It is striking, however, that affected children do have an odd facies, resulting from the association of a broad nose bridge, anteverted nares, and micrognathia. The broad maxillary ridges are characteristic. The pedal syndactyly is one of the most constant features of the syndrome. The narrow shoulders and short 
TABLE I

DERMATOGLYPHIC PATTERNS IN CASES $5,6,7,8$, AND 9

\begin{tabular}{|c|c|c|c|c|c|c|c|c|c|c|c|c|c|c|c|c|c|}
\hline & \multicolumn{10}{|c|}{ Digits } & \multicolumn{6}{|c|}{ Palms } & \multirow{3}{*}{$\frac{\text { Feet }}{\text { Hallucal Area }}$} \\
\hline & \multicolumn{2}{|c|}{ I } & \multicolumn{2}{|c|}{ II } & \multicolumn{2}{|c|}{ III } & \multicolumn{2}{|c|}{ IV } & \multicolumn{2}{|c|}{ V } & \multicolumn{2}{|c|}{$\begin{array}{l}\text { High } \\
\text { Tri- } \\
\text { radius }\end{array}$} & \multicolumn{2}{|c|}{$\begin{array}{l}\text { 3rd } \\
\text { Inter- } \\
\text { digit } \\
\text { Space } \\
\text { Loop }\end{array}$} & \multicolumn{2}{|c|}{$\begin{array}{l}\text { Simian } \\
\text { Crease }\end{array}$} & \\
\hline & Rt & $\mathbf{L t}$ & Rt & Lt & $\mathbf{R t}$ & Lt & $\mathbf{R t}$ & Lt & $\mathbf{R t}$ & Lt & $\mathbf{R t}$ & Lt & $\mathbf{R t}$ & Lt & $\mathbf{R t}$ & $\mathbf{L t}$ & \\
\hline $\begin{array}{l}\text { Family III } \\
\text { Mother } \\
\text { Father } \\
\text { Case } 5\end{array}$ & $\begin{array}{l}\mathbf{W} \\
\mathbf{U} \\
\mathbf{W}\end{array}$ & $\begin{array}{l}\mathbf{W} \\
\mathbf{U} \\
\mathbf{W}\end{array}$ & $\begin{array}{l}\mathbf{W} \\
\mathbf{W} \\
\mathbf{W}\end{array}$ & $\begin{array}{l}\mathbf{W} \\
\mathbf{W} \\
\mathbf{W}\end{array}$ & $\begin{array}{l}\mathbf{W} \\
\mathbf{W} \\
\mathbf{W}\end{array}$ & $\begin{array}{l}\mathbf{W} \\
\mathbf{U} \\
\mathbf{W}\end{array}$ & $\begin{array}{l}\mathbf{W} \\
\mathbf{W} \\
\mathbf{W}\end{array}$ & $\begin{array}{l}\mathbf{W} \\
\mathbf{W} \\
\mathbf{W}\end{array}$ & $\begin{array}{l}\mathbf{W} \\
\mathbf{W}\end{array}$ & $\begin{array}{l}\mathbf{W} \\
\mathbf{W}\end{array}$ & $\begin{array}{l}- \\
-\end{array}$ & $\begin{array}{l}- \\
-\end{array}$ & $\begin{array}{l}+ \\
+ \\
+\end{array}$ & $\begin{array}{l}+ \\
+ \\
-\end{array}$ & $\begin{array}{l}- \\
- \\
+\end{array}$ & $\begin{array}{l}- \\
+ \\
+\end{array}$ & $\begin{array}{l}\text { Not examined } \\
\text { Loop tibial Rt; loop } \\
\text { distal Lt } \\
\text { Whorl Rt; loop tibial Lt }\end{array}$ \\
\hline $\begin{array}{c}\text { Family IV } \\
\text { Muther }\end{array}$ & $\mathbf{U}$ & $\mathbf{U}$ & $\mathbf{A}$ & A & $\mathbf{U}$ & $\mathbf{A}$ & $\mathbf{W}$ & $\mathbf{W}$ & $\mathbf{U}$ & $\mathbf{U}$ & - & - & - & - & - & - & Small loop distal Rt and \\
\hline $\begin{array}{l}\text { Father } \\
\text { Case } 6 \\
\text { Case } 7\end{array}$ & $\begin{array}{l}\mathbf{U} \\
\mathbf{R} \\
\mathbf{U}\end{array}$ & $\begin{array}{l}\mathbf{W} \\
\mathbf{R} \\
\mathbf{W}\end{array}$ & $\begin{array}{l}\mathbf{W} \\
\mathbf{R} \\
\mathbf{W}\end{array}$ & $\begin{array}{l}\mathbf{W} \\
\mathbf{A} \\
\mathbf{W}\end{array}$ & $\underset{\mathbf{W}}{\mathbf{U}}$ & $\begin{array}{l}\mathbf{W} \\
\mathbf{W}\end{array}$ & $\begin{array}{l}\mathbf{W} \\
\mathbf{A} \\
\mathbf{W}\end{array}$ & $\begin{array}{l}\mathbf{W} \\
\mathbf{A} \\
\mathbf{W}\end{array}$ & $\underset{\mathbf{W}}{\mathbf{W}}$ & $\underset{\mathbf{W}}{\mathbf{W}}$ & $\overline{-}$ & $\begin{array}{l}+ \\
-\end{array}$ & $\underline{+}$ & $\begin{array}{l}- \\
+ \\
+\end{array}$ & $\begin{array}{l}- \\
+ \\
+\end{array}$ & $\overline{-}$ & $\begin{array}{l}\text { Open field Rt and Lt } \\
\text { Vestigial loop Rt and Lt } \\
\text { Vestigial loop Rt; loop } \\
\text { fibular Lt }\end{array}$ \\
\hline $\begin{array}{c}\text { Family } V \\
\text { Case } 8\end{array}$ & $\mathbf{U}$ & A & $\mathbf{R}$ & $\mathbf{R}$ & $\mathbf{A}$ & $\mathbf{R}$ & $\mathbf{W}$ & $\mathbf{R}$ & $\mathbf{A}$ & $\mathbf{U}$ & $?$ & + & $?$ & $?$ & + & + & Not analysable \\
\hline $\begin{array}{c}\text { Family VI } \\
\text { Mother } \\
\text { Father } \\
\text { Case } 9\end{array}$ & $\begin{array}{l}\mathbf{U} \\
\mathbf{U}\end{array}$ & $\begin{array}{l}\mathbf{U} \\
\mathbf{U}\end{array}$ & $\begin{array}{l}\mathbf{U} \\
\mathbf{A}\end{array}$ & $\begin{array}{l}\mathbf{U} \\
\mathbf{A} \\
\mathbf{R}\end{array}$ & $\begin{array}{l}\mathbf{U} \\
\mathbf{A} \\
\mathbf{U}\end{array}$ & $\begin{array}{l}\mathbf{U} \\
\mathbf{U}\end{array}$ & $\begin{array}{l}\mathbf{U} \\
\mathbf{W}\end{array}$ & $\begin{array}{l}\mathbf{W} \\
\mathbf{A} \\
\mathbf{W}\end{array}$ & $\begin{array}{l}\mathbf{U} \\
\mathbf{A} \\
\mathbf{W}\end{array}$ & $\underset{\mathbf{W}}{\mathbf{W}}$ & $\bar{z}$ & $\bar{z}$ & $\begin{array}{l}- \\
-\end{array}$ & $\overline{-}$ & $\overrightarrow{-}$ & $\overline{-}$ & $\begin{array}{l}\text { Not examined } \\
\text { Not examined } \\
\text { Loop distal Rt and Lt }\end{array}$ \\
\hline
\end{tabular}

A, arch; R, radial loop; U, ulnar loop; W, whorl; Rt, right; Lt, left.

TABLE II

BLOOD GROUP STUDIES-FAMILY IV

\begin{tabular}{l|llllllll}
\hline Mother & NSNs & Ce.ce & Fy ab & $\mathrm{Be}(\mathrm{a}-)$ & $\mathbf{W r}(\mathrm{a}-)$ & $\mathrm{Bu}(\mathrm{a}-)$ & Reid - \\
Father & MSMS & cDE.ce & Fy & ab & $\mathrm{Be}(\mathrm{a}-)$ & $\mathbf{W r}(\mathrm{a}-)$ & $\mathrm{Bu}(\mathrm{a}-)$ & Reid- \\
Case 6 & MSNs & ce.ce & Fy & ab & & & \\
Case 7 & MSNs & cDE.ce & Fy & bb & & & \\
\hline
\end{tabular}

All: $\mathrm{O} ; \mathbf{P}+; \mathrm{K}-\mathbf{k}+\mathrm{Kp}(\mathrm{a}-\mathrm{b}+) ; \mathrm{Lu}(\mathrm{a}-\mathrm{b}+) ; \mathbf{X g}(\mathrm{a}+) ; \mathrm{Bi}(\mathrm{a}-) ; \mathrm{Wiel}-; \mathrm{LW}+$; $\mathrm{Vel}+; \mathrm{Yt}(\mathrm{a}+)$

neck also help to delineate the phenotype. In males the hypospadias, cryptorchidism, and failure of development of the scrotum are frequently observed, while females apparently have a normal genital development. A progression from hypotonicity to spasticity has been observed. Other abnormal features of this syndrome are the failure to thrive and the frequent vomiting or regurgitating during infancy. The feeding problems are sometimes increased by the fact that some of the patients have a cleft palate or a pyloric stenosis. The dermatoglyphic patterns are often abnormal: most patients have a palmar transverse crease; and a high number of digital whorls has also been noted in several patients. However, an arch tibial pattern or a variant of it, in the hallucal area, as mentioned by Miller and Giroux (1966), is by no means a constant feature of the syndrome.
The abnormal findings from cases of this report and other reported cases are summarized in Table III. General terms like heart defect, ear defect, and abnormal feet were used to avoid a specific outline of anomalies which may not be typical of this syndrome: a ventricular septal defect and persistent ductus arteriosus may be present in association or as isolated anomalies; the ears could be low set, with or without hypoplastic cartilage development or other peculiarity; the abnormal position of the feet has been referred to by the authors as metatarsus or adductus, clubbed feet, or pes equinovarus, none of which is apparently found more commonly than the other. It is also interesting to note that while patients are hypotonic in the first months of life, they seem to become more spastic as they become older. Only 3 patients were found to have a sacral dimple (Smith et al., 1964; Kenis and Hustinx, 
TABLE III

SUMMARY OF CLINICAL FINDINGS

\begin{tabular}{|c|c|c|c|c|c|c|c|c|c|c|c|c|c|c|c|c|c|c|c|c|c|c|c|c|c|c|c|}
\hline \multirow[b]{2}{*}{$\begin{array}{l}\text { Cases } \\
\text { Sex }\end{array}$} & \multirow[b]{2}{*}{$\begin{array}{c}1 \\
F\end{array}$} & \multirow[b]{2}{*}{$\begin{array}{r}2 \\
\text { F }\end{array}$} & \multirow[b]{2}{*}{$\begin{array}{l}3 \\
M\end{array}$} & \multirow[b]{2}{*}{$\begin{array}{c}4 \\
F\end{array}$} & \multirow[b]{2}{*}{$\begin{array}{r}5 \\
F\end{array}$} & \multirow[b]{2}{*}{$\begin{array}{c}6 \\
M\end{array}$} & \multirow[b]{2}{*}{$\begin{array}{r}7 \\
\text { F }\end{array}$} & \multirow[b]{2}{*}{$\begin{array}{r}8 \\
F\end{array}$} & \multirow[b]{2}{*}{$\begin{array}{c}9 \\
M\end{array}$} & \multirow[b]{2}{*}{$\begin{array}{l}10 \\
M\end{array}$} & \multirow[b]{2}{*}{$\begin{array}{l}11 \\
\mathrm{M}\end{array}$} & \multirow[b]{2}{*}{$\begin{array}{l}12 \\
M\end{array}$} & \multirow[b]{2}{*}{$\begin{array}{l}13 \\
M\end{array}$} & \multirow[b]{2}{*}{$\begin{array}{l}14 \\
F\end{array}$} & \multirow[b]{2}{*}{$\begin{array}{l}15 \\
M\end{array}$} & \multirow[b]{2}{*}{$\begin{array}{l}16 \\
\mathrm{M}\end{array}$} & \multirow[b]{2}{*}{$\begin{array}{l}17 \\
F\end{array}$} & \multirow[b]{2}{*}{$\begin{array}{l}18 \\
\mathrm{M}\end{array}$} & \multirow[b]{2}{*}{$\begin{array}{l}19 \\
\mathrm{M}\end{array}$} & \multirow[b]{2}{*}{$\left|\begin{array}{l}20 \\
\mathrm{M}\end{array}\right|$} & \multirow[b]{2}{*}{$\begin{array}{l}21 \\
F\end{array}$} & \multirow[b]{2}{*}{$\begin{array}{l}22 \\
M\end{array}$} & \multirow[b]{2}{*}{$\begin{array}{l}23 \\
M\end{array}$} & \multicolumn{4}{|c|}{ Total (9 F, $14 \mathrm{M})$} \\
\hline & & & & & & & & & & & & & & & & & & & & & & & & + & - & ? & $\%+$ \\
\hline $\begin{array}{l}\text { Breech presentation } \\
\text { Birthweight < } 2500 \mathrm{~g} \text {. } \\
\text { Failure to thrive } \\
\text { Mental retardation } \\
\text { Hypotonicity } \\
\text { Hypertonicity } \\
\text { Microcephaly } \\
\text { Broad nose } \\
\text { Upturned nares } \\
\text { Micrognathia } \\
\text { Broad alveolar ridges } \\
\text { High palate } \\
\text { Cleft palate } \\
\text { Epicanthic folds } \\
\text { Blepharoptosis } \\
\text { Strabismus } \\
\text { Ear defect } \\
\text { Short neck } \\
\text { Heart defect } \\
\text { Pyloric stenosis } \\
\text { Flexed fingers } \\
\text { Polydactyly } \\
\text { Pedal syndactyly } \\
\text { Abnormal feet } \\
\text { Hypospadias } \\
\text { Cryptorchidism } \\
\text { Scrotum abnormal } \\
\text { Simian creases }\end{array}$ & $\begin{array}{l}- \\
\overline{+} \\
+ \\
+ \\
+ \\
+ \\
+ \\
+ \\
+ \\
+ \\
? \\
+ \\
+ \\
? \\
+ \\
+ \\
+ \\
+ \\
+ \\
? \\
+ \\
+ \\
+ \\
+\end{array}$ & $\begin{array}{l}- \\
+ \\
+ \\
+ \\
+ \\
+ \\
+ \\
+ \\
+ \\
+ \\
? \\
+ \\
+ \\
+ \\
? \\
+ \\
+ \\
+ \\
? \\
+ \\
+ \\
+ \\
+\end{array}$ & $\begin{array}{l}- \\
+ \\
+ \\
+ \\
+ \\
+ \\
+ \\
+ \\
+ \\
+ \\
+ \\
+ \\
+ \\
+ \\
+ \\
+ \\
+ \\
+ \\
+ \\
+ \\
+ \\
+ \\
+ \\
+ \\
+ \\
+\end{array}$ & $\begin{array}{l}- \\
+ \\
+ \\
+ \\
? \\
? \\
+ \\
+ \\
+ \\
+ \\
? \\
+ \\
+ \\
+ \\
? \\
+ \\
+ \\
+ \\
+ \\
? \\
+ \\
+ \\
+\end{array}$ & $\begin{array}{l}+ \\
\\
+ \\
+ \\
+ \\
+ \\
+ \\
+ \\
+ \\
+ \\
+ \\
+ \\
+ \\
+ \\
+ \\
+ \\
+ \\
+ \\
+ \\
+ \\
+ \\
+ \\
+ \\
+\end{array}$ & $\begin{array}{l}+ \\
+ \\
+ \\
+ \\
+ \\
+ \\
+ \\
+ \\
+ \\
+ \\
+ \\
+ \\
+ \\
+ \\
+ \\
+ \\
+ \\
+ \\
+ \\
+ \\
+ \\
+ \\
+ \\
+ \\
+\end{array}$ & $\begin{array}{l}- \\
\overline{+} \\
+ \\
+ \\
- \\
+ \\
+ \\
+ \\
+ \\
+ \\
+ \\
+ \\
+ \\
+ \\
+ \\
+ \\
+ \\
+ \\
+ \\
+ \\
+ \\
+ \\
+\end{array}$ & $\begin{array}{l}- \\
? \\
+ \\
+ \\
+ \\
- \\
- \\
+ \\
+ \\
+ \\
? \\
+ \\
+ \\
+ \\
? \\
+ \\
+ \\
+ \\
+ \\
? \\
+ \\
+ \\
+ \\
+\end{array}$ & $\begin{array}{l}- \\
+ \\
+ \\
+ \\
+ \\
+ \\
+ \\
+ \\
+ \\
+ \\
+ \\
+ \\
+ \\
+ \\
+ \\
+ \\
+ \\
+ \\
+ \\
+ \\
+ \\
+ \\
- \\
+ \\
+\end{array}$ & $\begin{array}{l}? \\
+ \\
+ \\
+ \\
+ \\
+ \\
+ \\
+ \\
+ \\
+ \\
+ \\
? \\
+ \\
+ \\
+ \\
\frac{?}{2} \\
? \\
? \\
+ \\
? \\
+ \\
+ \\
+ \\
+ \\
+ \\
+ \\
+\end{array}$ & $\begin{array}{l}+ \\
+ \\
+ \\
+ \\
+ \\
+ \\
+ \\
+ \\
+ \\
+ \\
+ \\
? \\
- \\
- \\
+ \\
? \\
? \\
? \\
+ \\
? \\
+ \\
+ \\
+ \\
+ \\
+ \\
+\end{array}$ & $\begin{array}{l}? \\
+ \\
+ \\
+ \\
+ \\
+ \\
+ \\
+ \\
+ \\
+ \\
? \\
+ \\
+ \\
+ \\
+ \\
+ \\
? \\
? \\
? \\
+ \\
+ \\
+ \\
+ \\
+\end{array}$ & $\begin{array}{l}? \\
+ \\
+ \\
+ \\
+ \\
+ \\
+ \\
? \\
? \\
? \\
? \\
? \\
? \\
? \\
? \\
? \\
? \\
? ? \\
? \\
? \\
? \\
? \\
? \\
? \\
?\end{array}$ & $\begin{array}{l}+ \\
+ \\
+ \\
+ \\
+ \\
+ \\
+ \\
+ \\
+ \\
+ \\
+ \\
+ \\
+ \\
+ \\
+ \\
? \\
? \\
? \\
+ \\
+ \\
+ \\
+ \\
-\end{array}$ & $\begin{array}{l}+ \\
+ \\
+ \\
+ \\
+ \\
+ \\
+ \\
+ \\
+ \\
+ \\
+ \\
+ \\
+ \\
+ \\
+ \\
? \\
? \\
? \\
+ \\
+ \\
+ \\
+ \\
+ \\
+ \\
+ \\
+\end{array}$ & $\begin{array}{l}- \\
+ \\
+ \\
+ \\
+ \\
+ \\
+ \\
+ \\
+ \\
+ \\
+ \\
+ \\
+ \\
+ \\
+ \\
+ \\
+ \\
? \\
? \\
+ \\
+ \\
+ \\
+ \\
+ \\
+ \\
+\end{array}$ & $\begin{array}{l}- \\
\bar{t} \\
+ \\
+ \\
\bar{y} \\
\bar{t} \\
+ \\
+ \\
+ \\
? \\
+ \\
\overline{+} \\
\overline{+} \\
+ \\
+ \\
? \\
\bar{?} \\
\bar{?} \\
\bar{?} \\
\overline{+} \\
\mathbf{b}\end{array}$ & $\begin{array}{l}+ \\
- \\
+ \\
+ \\
- \\
- \\
+ \\
+ \\
+ \\
? \\
? \\
? \\
- \\
+ \\
+ \\
+ \\
? \\
- \\
? \\
? \\
+ \\
+ \\
+ \\
+ \\
-\end{array}$ & $\begin{array}{l}+ \\
+ \\
+ \\
+ \\
? \\
- \\
+ \\
+ \\
+ \\
+ \\
? \\
+ \\
- \\
- \\
- \\
+ \\
+ \\
+ \\
+ \\
+ \\
+ \\
+ \\
+ \\
+ \\
+\end{array}$ & $\begin{array}{l}- \\
- \\
+ \\
+ \\
? \\
- \\
+ \\
+ \\
+ \\
+ \\
- \\
+ \\
- \\
- \\
- \\
- \\
+ \\
+ \\
? \\
- \\
+ \\
+ \\
+ \\
+ \\
+ \\
+ \\
+\end{array}$ & $\begin{array}{l}+ \\
+ \\
+ \\
+ \\
+ \\
+ \\
+ \\
+ \\
+ \\
+ \\
+ \\
+ \\
+ \\
+ \\
+ \\
+ \\
+ \\
? \\
+ \\
? \\
+ \\
+ \\
+\end{array}$ & $\begin{array}{l}- \\
- \\
+ \\
+ \\
+ \\
- \\
+ \\
+ \\
+ \\
+ \\
+ \\
+ \\
- \\
- \\
- \\
- \\
+ \\
+ \\
? \\
+ \\
+ \\
+ \\
+ \\
+ \\
+ \\
+ \\
+\end{array}$ & $\begin{array}{l}- \\
+ \\
+ \\
+ \\
+ \\
+ \\
+ \\
+ \\
+ \\
+ \\
- \\
- \\
- \\
+ \\
+ \\
+ \\
+ \\
? \\
? \\
\bar{?} \\
+ \\
+ \\
+ \\
+ \\
\bar{t} \\
? \\
?\end{array}$ & $\begin{array}{r}8 \\
6 \\
23 \\
23 \\
7 \\
11 \\
22 \\
22 \\
22 \\
21 \\
13 \\
17 \\
9 \\
17 \\
10 \\
16 \\
13 \\
6 \\
3 \\
10 \\
5 \\
21 \\
16 \\
9 \\
10 \\
9 \\
14\end{array}$ & $\begin{array}{r}12 \\
16 \\
0 \\
0 \\
13 \\
11 \\
1 \\
0 \\
0 \\
0 \\
2 \\
1 \\
10 \\
4 \\
10 \\
0 \\
0 \\
6 \\
17 \\
3 \\
17 \\
1 \\
6 \\
5 \\
4 \\
4 \\
3\end{array}$ & $\begin{array}{r}3 \\
1 \\
0 \\
0 \\
3 \\
1 \\
0 \\
1 \\
1 \\
2 \\
8 \\
5 \\
4 \\
2 \\
3 \\
7 \\
10 \\
11 \\
3 \\
10 \\
1 \\
1 \\
1 \\
0 \\
0 \\
1 \\
6\end{array}$ & $\begin{array}{r}40 \\
27 \\
100 \\
100 \\
35 \\
50 \\
96 \\
100 \\
100 \\
100 \\
87 \\
94 \\
47 \\
81 \\
50 \\
100 \\
100 \\
50 \\
15 \\
77 \\
29 \\
95 \\
73 \\
64 \\
71 \\
69 \\
82\end{array}$ \\
\hline
\end{tabular}

+ Present; - absent; ? undetermined or not mentioned.

^ Cases 1-9 this report; 10-13 Smith et al. (1964); 14-15 Pinsky and DiGeorge (1965); 16 Gibson (1965); 17-18 Blair and Martin (1966); 19-20 Dallaire and Fraser (1966); 21-22 Kenis and Hustinx (1967); and 23 Fine et al. (1968).

1967), and 2 had a cutaneous pit anterior to the anus (Smith et al., 1964; Pinsky and DiGeorge, 1965); these anomalies were not recorded in subsequent case reports. Four of the nine patients in this report were re-examined, and none had either of these two anomalies.

Genetic analysis. There are still only a few reports on the familial occurrence of this syndrome, but the available data clearly indicate a tendency for this syndrome to recur in families. Among 16 sibships (Table IV) including the 6 reported in this paper, there were 24 affected and 19 normal children. The distribution of affected to normal, excluding one proband per family, gives a value of $30 \%$ which does not deviate from the expected $25 \%$ value for autosomal recessive inheritance.

The sex ratio $1 \cdot 7: 1$ ( 15 males to 9 females) did

TABLE IV

DISTRIBUTION OF 16 RECORDED FAMILIES: SMITH-LEMLI-OPITZ SYNDROME

\begin{tabular}{|c|c|c|c|c|c|c|c|c|c|}
\hline \multirow{2}{*}{ Families } & \multirow{2}{*}{$\begin{array}{c}\text { Parental } \\
\text { Ethnic } \\
\text { Origin }\end{array}$} & \multirow{2}{*}{$\begin{array}{l}\text { Consan- } \\
\text { guinity }\end{array}$} & \multirow{2}{*}{$\begin{array}{c}\text { Paternal } \\
\text { Age` } \\
\text { (yr.) }\end{array}$} & \multirow{2}{*}{$\underset{\substack{\text { Maternal } \\
\text { (yr.) }}}{\text { (yge }}$} & \multirow{2}{*}{ Miscarriages } & \multicolumn{2}{|c|}{ Affected } & \multirow{2}{*}{ Normal } & \multirow{2}{*}{$\underset{\text { Size }}{\text { Family }}$} \\
\hline & & & & & & Males & Females & & \\
\hline 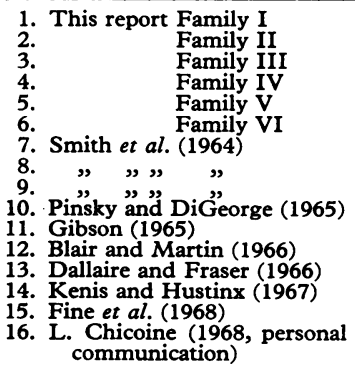 & $\begin{array}{l}\text { F.C. } \\
\text { F.C. } \\
\text { F.C. } \\
\text { E.C. } \\
\text { E.C. } \\
\text { F.C. } \\
\text { Amer. } \\
\text { Amer. } \\
\text { Amer. } \\
\text { Amer. } \\
\text { E.C. } \\
\text { E.C. } \\
\text { F.C. } \\
\text { Net. } \\
\text { Amer. } \\
\text { F.C. }\end{array}$ & $\begin{array}{l}\text { No } \\
\text { No } \\
\text { No } \\
\text { No } \\
\text { No } \\
\text { No } \\
\text { No } \\
\text { No } \\
\text { No } \\
\text { No } \\
\text { No } \\
\text { No } \\
\text { No } \\
\text { No } \\
\text { No } \\
\text { Yes }\end{array}$ & $\begin{array}{l}28 \\
28 \\
23 \\
30 \\
41 \\
26 \\
30 \\
27 \\
27 \\
22 \\
27 \\
25 \\
27 \\
29 \\
22 \\
25\end{array}$ & $\begin{array}{l}26 \\
27 \\
21 \\
29 \\
30 \\
23 \\
25 \\
25 \\
25 \\
21 \\
21 \\
21 \\
20 \\
29 \\
19 \\
\\
22\end{array}$ & $\begin{array}{l}4 \\
0 \\
0 \\
0 \\
0 \\
0 \\
2 \\
0 \\
1 \\
0 \\
1 \\
0 \\
1 \\
0 \\
0 \\
2\end{array}$ & $\begin{array}{l}1 \\
0 \\
0 \\
1 \\
0 \\
1 \\
1 \\
1 \\
2 \\
1 \\
1 \\
1 \\
2 \\
1 \\
1 \\
1\end{array}$ & $\begin{array}{l}2 \\
1 \\
1 \\
1 \\
1 \\
0 \\
0 \\
0 \\
0 \\
1 \\
0 \\
1 \\
0 \\
1 \\
0 \\
0\end{array}$ & $\begin{array}{l}5 \\
4 \\
0 \\
0 \\
1 \\
1 \\
2 \\
0 \\
2 \\
1 \\
1 \\
0 \\
2 \\
0 \\
0 \\
0\end{array}$ & $\begin{array}{l}8 \\
5 \\
1 \\
2 \\
2 \\
2 \\
3 \\
1 \\
4 \\
3 \\
2 \\
2 \\
4 \\
2 \\
1 \\
1\end{array}$ \\
\hline
\end{tabular}

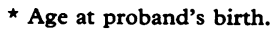

Amer.: American; E.C.: English Canadian; F.C. French Canadian; Net.: Netherlands. 
not deviate significantly from the expected $1: 1$ ratio. The apparent excess of males could thus be a random fluctuation, or could be due to the fact that the diagnosis would be made more easily in males because of the hypospadias and the cryptorchidism exhibited by most of them.

The mean paternal age was $27 \cdot 3$ years and the mean maternal age 24.0 years at the time of birth of the proband, so there is no suggestion of a relation with advanced paternal age. The blood group data were insufficient to permit meaningful analysis: the postulated recessive genes for the syndrome showed recombination with $\mathrm{CDE}$ locus and the Fy locus, but not with the MNS locus; however, there was only one opportunity in each case to observe recombination.

In 1 of the 16 families included in Table IV, the parents were first cousins; whether this represents raised consanguinity rate cannot be decided on the basis of the available data. In Family I of this report a first cousin was probably affected, and in Family III a first cousin was born with multiple anomalies that may have represented the syndrome. Both these cases were included since they had several of the abnormal features seen in other cases.

The ratio of affected to unaffected sibs is compatible with autosomal recessive inheritance. However we have previously suggested (Dallaire and Fraser, 1966) that a chromosomal aberration would also account for the observations. A minute reciprocal translocation in the parents, involving, for instance, chromosome 18 and another autosome, might remain undetectable in the affected child and the carrier parent. Furthermore, this would lead to the production of deficient or disomic gametes: it would then be expected that variations in the phenotype would occur between families, because of variations in length of the abnormal segment. In addition, one might find, in the same sibship, children with abnormal features resulting from the deletion of a segment and others with malformations resulting from the presence of a segment in triplicate.

\section{Summary}

Among 6 families, 9 children presented a syndrome of retardation, with urogenital and skeletal anomalies. From the study of these children and others recently reported, several anomalies such as cleft palate, heart defect, pyloric stenosis, and polydactyly appear inconstant features of the syndrome originallv described bv Smith et al. Thnnoh most

affected children present a combination of several anomalies common to a number of syndromes, the distinctive features of the phenotype are the odd facies resulting from the association of blepharoptosis, anteverted nares, and micrognathia, broad maxillary ridges, and pedal syndactyly involving the second and third toes. The males usually have a hypospadias and cryptorchidism, while females have normal external genitalia. A review of 16 families showed that the frequency of the syndrome in sibs of affected children is $30 \%$; this does not differ significantly from $25 \%$. The mean maternal age was 24.0 years and the mean paternal age 27.2 years at the time of birth of the first affected child. The similarity of the somatic abnormalities, to others found in autosomal aberrations, could be due to an undetectable chromosomal aberration. However, until proven otherwise, the cause of the syndrome is assumed to be an autosomal recessive gene.

The author wishes to express his thanks to Dr. B. Chown for blood grouping; to Drs. F. C. Fraser and L. Pinsky for their kind advice; to Miss S. O'Brien for her technical assistance.

\section{REFERENCES}

Blair, H. R., and Martin, J. K. (1966). A syndrome characterized by mental retardation, short stature, craniofacial dysplasia and genital anomalies occurring in siblings. $f$. Pediat., 69, 457.

Dallaire, L., and Fraser, F. C. (1966). The syndrome of retardation with urogenital and skeletal anomalies in siblings. ibid., 69, 459.

Fine, R. N., Gwinn, J. L., and Young, E. F. (1968). Smith-LemliOpitz syndrome. Radiologic and postmortem findings. Amer. f. Dis. Child., 115, 483.

Gibson, R. (1965). A case of the Smith-Lemli-Opitz syndrome of multiple congenital anomalies in association with dysplasia epiphysialis punctata. Canad. med. Ass. F., 92, 574.

Kenis, H., and Hustinx, W. J. (1967). A familial syndrome of mental retardation in asssociation with multiple congenital anomalies resembling the syndrome of Smith-Lemli-Opitz. Maandschr. Kindergeneesk., 35, 37.

Miller, J. R., and Giroux, J. (1966). Dermatoglyphics in pediatric practice. F. Pediat., 69, 302.

Moorhead, P. S., Nowell, P. C., Mellman, W. J., Battips, D. M., and Hungerford, D. A. (1960). Chromosome preparations of leukocytes cultured from human peripheral blood. Exp. Cell Res., 20, 613.

Pinsky, L., and DiGeorge, A. M. (1965). A familial syndrome of facial and skeletal anomalies associated with genital abnormality in the male and normal genitals in the female. Another case of male pseudohermaphroditism. F. Pediat., 66, 1049.

Smith, D. W., Lemli, L., and Opitz, J. M. (1964). A new recognized syndrome of multiple congenital anomalies. ibid., 64, 210.

\section{Addendum: Case Identification}

Case 1 (PB 111050)

Case 2 (JB 111053)

Case 3 (DB 051157)

Case 4 (CC 150851)

Case 5 (SA 021165)
Case 6 (RM 060956)

Case 7 (JM 271258)

Case 8 (MK 170863)

Case 9 (MC 260168) 